doi: $10.2306 /$ scienceasia1513-1874.2013.39.219

\title{
Conservation through in vitro propagation and restoration of Mahonia leschenaultii, an endemic tree of the Western Ghats
}

\author{
R.K. Radha*, Amy Mary Varghese, S. Seeni \\ Plant Biotechnology Division, Tropical Botanic Garden and Research Institute, Pacha-Palode P.O., \\ Thiruvananthapuram 695562 India
}

*Corresponding author, e-mail: radhapkumar@rediffmail.com

Received 10 Nov 2010

Accepted 26 Oct 2012

\begin{abstract}
Conservation of Mahonia leschenaultii was achieved through multiple axillary shoot formation in single node cultures, in vitro and ex vitro rooting of the shoots, and successful reintroduction and establishment of the rooted plants in the forests of Palani hills in Southern India. A preliminary experiment on the culture of young nodal explants $(1.0-1.5 \mathrm{~cm})$ from field-grown plants in different basal nutrient media revealed high frequency bud beak in Schenk and Hildebrandt (SH) medium followed by Woody Plant medium and Murashige Skoog medium in 4 weeks. Subsequent culture of both shoot tips $(0.5-0.8 \mathrm{~cm})$ and nodes for 6 weeks in SH medium supplemented with various concentration of cytokinins resulted in optimal formation of 3.6 shoots in $80 \%$ of the nodes against 1.35 shoots in $75 \%$ of the shoot tips in the presence of 2.0 and $1.0 \mathrm{mg} / \mathrm{l}$ benzyl adenine (BA), respectively. Invariably, the resident apical and axillary meristems grew into a single shoot $(1.0-1.8 \mathrm{~cm})$ in 1-2 weeks followed by the characteristic differentiation of additional buds from its base. A synergistic combination of $1.0 \mathrm{mg} / 1 \mathrm{BA}$ and $0.02 \mathrm{mg} / 1$ indole-3-acetic acid (IAA) induced the maximum number (5.9) of axillary shoot formation which were relatively high $(75 \%)$ when the explant was collected during May-June and the fifth nodes from the top of the growing shoots were used. Repeated subculture of the nodes from shoot cultures at 5-6 week intervals in medium supplemented with reduced concentrations of the growth regulators $(0.5 \mathrm{mg} / \mathrm{l} \mathrm{BA}, 0.01 \mathrm{mg} / \mathrm{lAA})$ through at least 10 passages enabled consistent production of 6-7 shoots per node at $92 \%$ success rate without loss of vigour, growth and morphological abnormalities. Shoots of 3-6 cm were rooted in vitro in the presence of $1.0 \mathrm{mg} / \mathrm{l}$ indole-3-butyric acid (IBA) and hardening in the mist house at 76-78\% and these rooted plants established in a potting medium of river sand and top soil (1:1) under constant mist irrigation. The plants reared in the nursery for 5-8 weeks were successfully reintroduced into the natural forest segment of the Institute's campus (MSL $200 \mathrm{~m}$ ) at Palode and Vattakanal shola forests of Palani hills (MSL $2500 \mathrm{~m}$ ) with establishment frequencies of 78.8 and 90.6, respectively, after 18 months. Growth characteristics of the plants (height, number of leaves and branches) reintroduced into native habitat at Vattakanal were better than those at Palode. Genetic fidelity of the 12-month old plants established in the nursery/field was confirmed by analysis of amplified products of genomic DNA obtained with random primers.
\end{abstract}

KEYWORDS: endemic medicinal plant, micropropagation, reintroduction, tropical montane forest, shola forest

\section{INTRODUCTION}

The Western Ghats region in peninsular India, a known biodiversity hotspot harbours around 4000 angiosperms of which about 1600 are endemics. The summits of certain ranges $(>2500 \mathrm{~m})$ in the Western Ghats are inhabited to a limited extent by a few such genera as Rhododendron, Thalictrum, Hypericum, and Mahonia that are commonly distributed in the Himalayas. Largely due to increased urbanization, tourism and plantation activities particularly in Munnar, Nilgiris, and Palani ranges in south Western Ghats, these high altitude taxa are being depleted at an alarming rate. Although Rhododendron arboreum is known for its horticultural value, chemical investigations have confirmed the presence of high value therapeutic agents such as berberine in Thalictrum javanicum and M. leschenaultii and hypericin in Hypericum perforatum and all these species are even otherwise important for retaining the ecological characteristics of the specific niches they inhabit, conservation efforts are particularly lacking. But for the isolated effort of the Palani Hills Conservation Council, which in the late 1990's lead a movement against the abuse of the characteristic shola forests in the region, institutional initiatives aimed at ecopreservation and conservation 
of the hill top flora are negligible.

Micropropagation through plant tissue culture offers opportunities for the conservation of endemic, endangered and difficult to propagate plant taxa are explained by several studies ${ }^{1}$. M. leschenaultii Nutt. (Berberidaceae), an endemic woody shrub or a small tree of the Western Ghats ${ }^{2}$ has immense medicinal applications in both conventional and modern medicine. The roots and woody stem are an excellent source of berberine having antitumour properties and are used as antimutagenic ${ }^{3}$, alterative, astringent, stomachic, diaphoretic, and gentle aperient, curative of piles and periodic neuralgia. The plant is extensively reported in Indian traditional systems of medicine such as Ayurvedha, Sidha, Unani ${ }^{4}$, and in tribal medicine ${ }^{5}$. Berberine is reported to inhibit cell growth by suppressing the expression of cyclin B1 and inhibiting CDC2 kinase activity in human cancer cells ${ }^{6}$. Seeds of $M$. leschenaultii rarely germinate under natural conditions. Experiments carried out in our laboratory suggest that more than $80 \%$ of the seeds are sterile at the time of collection while the rest belong to recalcitrant/intermediate types. Conventional propagation by vegetative cuttings is slow with low success $(<20 \%)$ rate. The spiny nature of the plants together with the requirement of acidic retentive humus soil for its establishment and performance has further compounded the difficulties of propagation and establishment of the plants. Non-conventional propagation is also challenging as the flushing of young shoots and consequently availability of young explants is confined to a short period in a year, newly formed shoots become quite hardy within 4-6 months and exudation from cut ends of young shoots is excessive. Despite these limitations owing to the importance of these species, the present study was undertaken to develop a rapid clonal propagation system by using nodal and shoot tip explants of flowering trees and test its application for conservation through reintroduction of the micropropagated plants into selected forest segments of the Western Ghats. Perusal of the literature revealed very little information on tissue culture of this species, though in vitro propagation of berberine-rich Berberis thunbergii ${ }^{7}$, high berberine producing cells of Coptis japonica ${ }^{8}$ and bioproduction of berberine in callus tissues of Thalictrum minus ${ }^{9}$ and cell cultures of Coscinium fenestratum ${ }^{10}$ are reported.

\section{MATERIALS AND METHODS}

Actively growing plants of 1.0-1.5 m height collected with the root system from Vattakanal tropical montane cloud forests (shola) of the Palani hills in the Southern Western Ghats were collected and planted in the Field
Gene Bank of the Institute. Newly emerging shoots with five or six nodes collected from the plants were used as source of explants. After leaf excision, the cuttings each with 3-5 nodes were treated with $1 \%$ Labolene detergent (Glaxo India Ltd., Mumbai) in a beaker for $10 \mathrm{~min}$. followed by continuous washing in running tap water for 10-20 min. Surface decontamination of the cuttings was done by immersion under stirring in $0.1 \%(\mathrm{w} / \mathrm{v}) \mathrm{HgCl}_{2}$ for 5-10 min. followed by five rinses with sterile distilled water. Shoot tips $(0.5-0.8 \mathrm{~cm})$ and single nodes $(1.0-1.5 \mathrm{~cm})$ were dissected and rinsed once in sterile distilled water to remove the yellow exudate before transfer to nutrient medium. The explants were implanted into $15 \mathrm{ml}$ aliquots of SH agar medium ${ }^{11}$ in $25 \times 150 \mathrm{~mm}$ culture tubes, in such a way that the node was in contact with the surface of the medium. The $\mathrm{pH}$ of the medium was adjusted to 5.8 before $0.5 \%(\mathrm{w} / \mathrm{v})$ agar (CDH India Ltd., New Delhi) and plant growth regulators (PGRs) were added and autoclaved at $121{ }^{\circ} \mathrm{C}$ under $15 \mathrm{~kg} / \mathrm{cm}^{2}$ pressure. The medium was supplemented with different concentrations of cytokinins (BAP and $\mathrm{Kn}$ ) and combinations of benzyl adenine (BA) and auxins indole-3-acetic acid (IAA) and 1-naphthaleneacetic acid (NAA).

Shoot initiation experiments were conducted in two steps. The initial experiment was for the selection of nutrient formulation. The selected SH medium was treated with different concentrations of BA (0.5$5.0 \mathrm{mg} / \mathrm{l})$ and combinations of BA and IAA/NAA $(0.01-0.1 \mathrm{mg} / \mathrm{l})$ for best shoot initiation. Each treatment consisted of 25 replicates with one explant per culture tube and was repeated twice. Experiments on shoot multiplication were carried out after 6 weeks of shoot initiation. Regeneration potential of shoot tips and nodes in terms of frequency and number of shoot formation was evaluated by culturing on $\mathrm{SH}$ medium supplemented with $0.5-5.0 \mathrm{mg} / \mathrm{l}$ BA alone or in combinations of BA $(0.05-5.0 \mathrm{mg} / \mathrm{l})$ and different concentrations of IAA $(0.01-0.1 \mathrm{mg} / \mathrm{l})$. Mass propagation was achieved by repeated subculture of the appropriate explants on medium supplemented with $1.0 \mathrm{mg} / \mathrm{l} \mathrm{BA}$ and $0.2 \mathrm{mg} / \mathrm{l} \mathrm{IAA}$ at $5-6$ weeks intervals. Shoots of $3 \mathrm{~cm}$ excised from the proliferated shoot cultures were used for root initiation in agar gelled SH medium containing different concentrations (0.05-2.0 mg/l) of auxins (IAA, IBA, and NAA). Six weeks after root initiation, the rooted plants were weaned from the culture vessels, washed well and transplanted in $5 \times 5 \mathrm{~cm}$ clay pots containing different potting mixtures of river sand and top soil (1:1), river sand, top soil and farmyard manure (1:1:1) and kept in a mist chamber. The plants were well irrigated 
for 4 weeks in a mist chamber maintained at $35^{\circ} \mathrm{C}$ and $90 \%$ RH. A set of shoots was also used for ex vitro rooting in the green house under constant temperature and relative humidity. Established plants were transferred to $15 \mathrm{~cm}$ pots with fresh potting mixture and maintained under diffused light in the nursery for at least 5-8 weeks for further growth before reintroduction into forest segments. Data were statistically analysed by ANOVA and means were compared by Duncan's multiple range test $(p<0.05)$ using SPSS/PC+ 4.0 (SPSS Inc., Chicago, USA).

Evergreen shola forest segment of Vattakanal in Palani Hills was selected for reintroduction of the micropropagated plants with logistical and technical assistance rendered by Tanya Balcar, Vattakanal Conservation Trust. A batch of microplants was also reintroduced into the natural forest segments within the TBG\&RI campus at Palode. The plants were carefully transferred to the forest patches in the month of May with spacing of $4 \mathrm{~m}$ pits and irrigated daily until they got established during the southwest monsoon rains of June. Periodical monitoring of the establishment of reintroduced plants was done and data on survival rate of the plants were collected at 5-6 month intervals for a period of 18 months. Growth was measured in terms of height of the plants and number of leaves of 10 randomly selected regenerated plants.

\section{RANDOM AMPLIFIED POLYMORPHIC DNA ANALYSIS (RAPD)}

\section{Extraction of genomic DNA}

Total genomic DNA from the young leaves (4 g) of both mother plant and tissue culture raised plants established in the nursery were isolated using CTAB following modified Murray and Thompson method ${ }^{12}$.

\section{RAPD assay}

RAPD assay was carried out in $25 \mu \mathrm{l}$ reaction mixture containing $2.5 \mu \mathrm{l} 10 \times$ amplification buffer $(500 \mathrm{mM}$ $\mathrm{KCl}, 100 \mathrm{mM}$ Tris $\mathrm{HCl}, 1.0 \%$ Triton $\mathrm{X}-100$, and $15 \mathrm{mM} \mathrm{MgCl}_{2}$ ), $100 \mu \mathrm{l}$ each of dATP, dGTP, cCTP, and dTTP, $1.0 \mathrm{U}$ of Taq DNA primer (Operon Technologies Inc, USA), and $50 \mu \mathrm{g}$ genomic DNA. Amplification was performed in PTC 100 (MJ Research Thermal Cycler). The sequential steps were: 1 cycle of $2 \mathrm{~min}$ at $93{ }^{\circ} \mathrm{C}, 2 \mathrm{~min}$ at $35^{\circ} \mathrm{C}$, and $2 \mathrm{~min}$ at $72^{\circ} \mathrm{C}$ followed by 38 cycles of $1 \mathrm{~min}$ at $93{ }^{\circ} \mathrm{C}, 1 \mathrm{~min}$ at $36^{\circ} \mathrm{C}$ and $2 \mathrm{~min}$ at $72^{\circ} \mathrm{C}$. The last cycle was followed by 10 min extension at $72^{\circ} \mathrm{C}$.

\section{Agarose gel electrophoresis and estimation of genetic uniformity}

The amplified products were resolved on $1.2 \%$ agarose gel $(1 \times \mathrm{TBE})$ followed by EtBr staining and the bands selected were documented using Alpha Chemiimager. Amplified products that were reproducible and consistent in performance were chosen for data Analysis.

The computer programs POPGENE and PCO3D were used to estimate genetic variability measures from data obtained in RAPD assay. The bands were represented by numbers (0-1) for RAPD data analysis.

\section{RESULTS}

Initially single nodal explants were tested in different basal nutrient formulations. High frequency and easy bud break occurred in SH (70) medium followed by WPM (50), MS (45), and B5 (43). Different explant types (shoot tip, node, internode and leaf segments) cultured in SH basal medium showed significant differences in their responses. Shoot tips invariably showed longitudinal growth to attain a length of $2 \mathrm{~cm}$ in length in 4 weeks, while in $49 \%$ of the nodal explants, axillary bud developed into single shoot of $2.0-2.5 \mathrm{~cm}$ length. None of the explants showed callusing in the basal medium. Leaf and internodal segments failed to show any morphogenic response even after 7 weeks of culture in any of the media. However, all the explant types released yellowish brown exudate from the cut ends to varied extent, which did not appear to inhibit apical, or axillary bud emergence as the case may be. Bud emergence in explants cultured in MS, B5 and WPM media was often delayed and the shoots attained a length of 0.5$2.5 \mathrm{~cm}$ in 4 weeks.

\section{Influence of PGR(s)}

Between the cytokinins tested, BA was more effective than $\mathrm{Kn}$ in inducing multiple shoot formation accompanied by varied degrees of callus formation especially at cut ends of the explants. Shoot formation was induced in shoot tip and nodal segments and not in foliar and internodal explants even after 8 weeks of culture in SH medium containing different concentrations of BA. None of the combinations of BA and NAA tested had stimulatory effect on shoot initiation more than individual concentration of BA, though callusing from the cut ends was pronounced. Apical and axillary bud break occurred within a week (Fig. 1a), the highest frequency of shoot formation recorded in shoot tip (75\%) and nodal explants $(80 \%)$ in the 

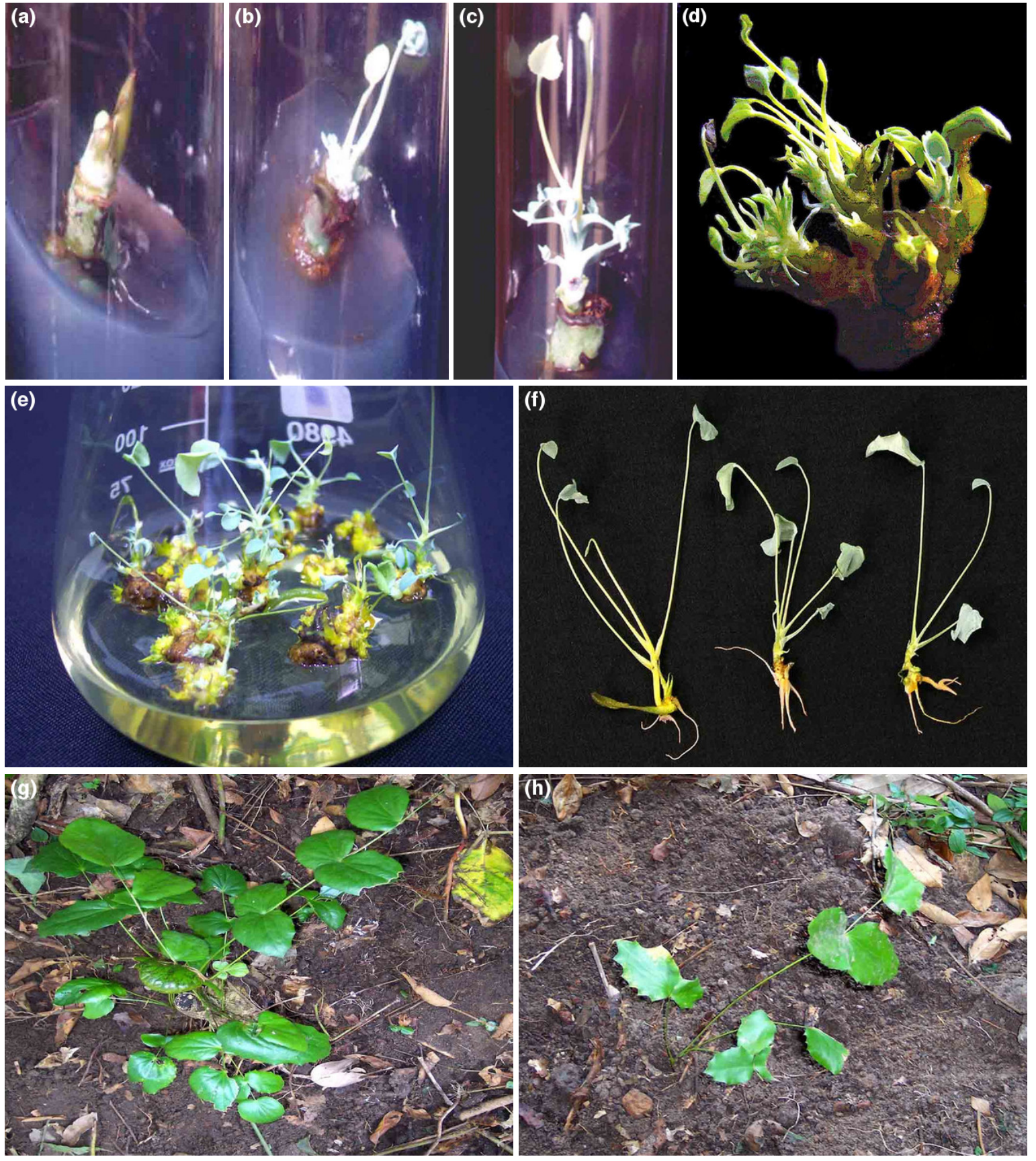

Fig. 1 In vitro propagation of M. leschenaultii on SH medium. (a) Apical meristem initiation after 2 weeks from shoot tip explants on medium with $1.0 \mathrm{mg} / \mathrm{l} \mathrm{BA}$. (b) Additional buds were formed from the base of the initiated apical meristem after 3 weeks. (c) Axillary bud developed into single shoot within 2 weeks on SH basal medium. (d) Multiple shoot bud formation on nodal explants with $1.0 \mathrm{mg} / \mathrm{l} \mathrm{BA}$ and $0.02 \mathrm{mg} / \mathrm{l}$ IAA after 4 weeks. (e) Shoot proliferation from the nodal explants after 6 weeks of subculture on $0.5 \mathrm{mg} / \mathrm{l}$ BAP. (f) Rooted mericlones after 5 weeks of culture in medium containing $1.0 \mathrm{mg} / \mathrm{l} \mathrm{BA}$. (g) Micropropagated plants established in community pots after 7 weeks hardening in mist chamber. (h) Establishment of micropropagated plants in natural forest habitat (Palni hills), 120 days after reintroduction. 
Table 1 Shoot initiation from shoot tip explants of M. leschenaultii in SH medium supplemented with different concentration of cytokinins. Observations were made after 6 weeks of culture.

\begin{tabular}{lcccc}
\hline $\begin{array}{l}\text { Cytokinin } \\
(\mathrm{mg} / \mathrm{l})\end{array}$ & $\begin{array}{c}\text { Response } \\
(\%)\end{array}$ & $\begin{array}{c}\text { Mean no. of } \\
\text { shoots/shoot tip }\end{array}$ & $\begin{array}{c}\text { Mean shoot } \\
\text { length }(\mathrm{cm})\end{array}$ & $\begin{array}{c}\text { Mean no. of } \\
\text { nodes/shoot }\end{array}$ \\
\hline BAP & & & & \\
0.0 & 55 & $1.0^{\mathrm{c}}$ & $3.12^{\mathrm{bc}}$ & $2.4^{\mathrm{c}}$ \\
0.5 & 69 & $1.25^{\mathrm{b}}$ & $3.10^{\mathrm{bc}}$ & $2.6^{\mathrm{b}}$ \\
1.0 & 75 & $1.5^{\mathrm{a}}$ & $3.6^{\mathrm{a}}$ & $2.8^{\mathrm{a}}$ \\
2.0 & 73 & $1.2^{\mathrm{b}}$ & $3.38^{\mathrm{ab}}$ & $2.3^{\mathrm{cd}}$ \\
3.0 & 74 & $1.0^{\mathrm{c}}$ & $3.07^{\mathrm{c}}$ & $2.2^{\mathrm{cd}}$ \\
4.0 & 77 & $1.1^{\mathrm{bc}}$ & $2.27^{\mathrm{f}}$ & $2.1^{\mathrm{cd}}$ \\
5.0 & 69 & $1.0^{\mathrm{c}}$ & $2.0^{\mathrm{gh}}$ & $1.7^{\mathrm{ef}}$ \\
$\mathrm{Kn}$ & & & & \\
0.5 & 53 & $1.2^{\mathrm{b}}$ & $2.35^{\mathrm{ef}}$ & $2.1^{\mathrm{d}}$ \\
1.0 & 45 & $1.1^{\mathrm{bc}}$ & $2.5^{\mathrm{de}}$ & $2.6^{\mathrm{b}}$ \\
2.0 & 55 & $1.0^{\mathrm{c}}$ & $2.74^{\mathrm{d}}$ & $2.6^{\mathrm{b}}$ \\
3.0 & 55 & $1.0^{\mathrm{c}}$ & $2.94^{\mathrm{cd}}$ & $2.6^{\mathrm{b}}$ \\
4.0 & 56 & $1.0^{\mathrm{c}}$ & $2.26^{\mathrm{f}}$ & $2.6^{\mathrm{bc}}$ \\
5.0 & 57 & $1.0^{\mathrm{c}}$ & $2.1^{\mathrm{gh}}$ & $2.4^{\mathrm{cd}}$ \\
\hline
\end{tabular}

Mean values $(n=25)$ within the same column followed by the same subscript(s) are not significantly different $(p<0.05)$ according to ANOVA and LSD multiple range test.

presence of $1 \mathrm{mg} / \mathrm{l}$ and $2.0 \mathrm{mg} / \mathrm{l} \mathrm{BAP}$, respectively (Table 1 and Table 2). The shoot tip showed longitudinal growth $(1.8 \mathrm{~cm})$ within a week and additional 1-2 buds were formed from its base after 2 weeks (Fig. 1b). In nodal explants, each axillary bud developed into a shoot of $1 \mathrm{~cm}$ in 2 weeks (Fig. 1c) and additional buds were formed from its base from the third week onwards. The growth of the first formed shoot in both shoot tip and node cultures was either reduced or arrested after the differentiation of additional buds from the base. After 6 weeks of culture a maximum of 1.5 and 3.6 shoots were formed in 75 $80 \%$ of the shoot tip and nodal segments, respectively (Table 1 and Table 2). Low frequency formation of shoots was recorded at both the both at lower and higher concentrations of BA, though the latter retarded shoot growth and induced callus formation from the basal cut ends proportionate to the increase in the concentration. Fewer and longer shoots were obtained in media containing $\mathrm{Kn}$. Leaf and internodal segments did not respond for caulogenesis but formed compact yellow callus at the cut ends in the presence of high concentrations of BA and IAA. Among the individual concentrations of BA tested, callus formation was maximum at $3.0 \mathrm{mg} / \mathrm{l} \mathrm{BA}$ beyond which the already formed calli showed signs of decline with browning and necrosis in 8 weeks. Initial experiments on caulogenesis using BA and $\mathrm{Kn}$ revealed that BAP alone was sufficient to trigger the growth of axillary meristems in nodal explants into shoots. However, addition of IAA with BA was found beneficial for both multiple shoot formation and shoot elongation at the same frequency as with BA alone (Table 2). Maximum number of 5.9 shoots $(78 \%)$ with mean length of $3.7 \mathrm{~cm}$ in node cultures were obtained (Fig. 1d) in medium containing $1.0 \mathrm{mg} / \mathrm{l} \mathrm{BA}$ and $0.02 \mathrm{mg} / \mathrm{l} \mathrm{IAA}$. This accelerated shooting response was specific to this combination. In other combinations frequency, number and elongation of shoots were less and in combinations of higher concentrations of BA and IAA, callus proliferation was pronounced.

\section{Influence of season and age of explants}

Seasonal influence on shoot formation, if any, was tested with nodal explants collected and cultured during different months of the year. Higher frequency bud break (75-80) coupled with maximum number (3.5) of shoot formation occurred in the presence of $2.0 \mathrm{mg} / \mathrm{l} \mathrm{BA}$ in nodal explants collected during May and June, compared to other months. The explants collected during July-October showed high rate $(>$ $40 \%$ ) of contamination. Of the different explants collected from the top shoot cuttings (first to fifth nodes), the fifth node from above produced responded with maximum frequency (79) and number of shoots (3.8), while the first and second nodes produced fewer number of shoots than the third and fourth nodes. Although the shoot tip responded similar (75\%) rate, only 1-2 shoots were formed and the shoots formed were longer $(>4.5 \mathrm{~cm})$ than the node derived ones $(2.7-3.7 \mathrm{~cm})$.

\section{Subculture}

During subculture, the nodal explants responded with higher frequencies of larger number of shoot formation than the shoot tips (Table 4) Both axillary and apical shoot break occurred in 7-10 days followed by the differentiation of $1.3-6.2$ shoots $(2.0 \mathrm{~cm})$ in $61-$ $97 \%$ of the explants within 5 weeks (Fig. 1e). Medium supplemented with $0.5 \mathrm{mg} / \mathrm{l} \mathrm{BA}$ induced maximum number (node 5.5 and shoot tip 2.8) of shoots per explant without any callusing. The morphogenic responses were further enhanced using a combination of $0.5 \mathrm{mg} / \mathrm{l} \mathrm{BA}$ and $0.01 \mathrm{mg} / \mathrm{l}$ IAA to produce 67 shoots in $92 \%$ of the nodes free of callusing. The repeated subculture of the nodes of shoot cultures up to 10 cycles each at 6 week intervals using this combination enabled continuous production of shoots without loss of vigour, callusing and morphological and growth abnormalities (Fig. 2). 
Table 2 Shoot initiation in isolated young nodes of $M$. leschenaultii in SH medium supplemented with various concentrations of BAP and $\mathrm{KN}$ and combinations of BAP and auxins (IAA/NAA). Nodes of third to fifth position from the top of the shoot were used for the experiments. Observations were made after 6 weeks of culture.

\begin{tabular}{|c|c|c|c|c|c|c|}
\hline \multicolumn{2}{|c|}{$\begin{array}{c}\text { PGR(s) } \\
(\mathrm{mg} / \mathrm{l})\end{array}$} & $\begin{array}{c}\text { Response } \\
(\%)\end{array}$ & $\begin{array}{c}\text { Mean } \\
\text { no. of } \\
\text { shoots/ } \\
\text { node }\end{array}$ & $\begin{array}{c}\text { Mean } \\
\text { shoot } \\
\text { length } \\
(\mathrm{cm})\end{array}$ & $\begin{array}{l}\text { Mean } \\
\text { no. of } \\
\text { nodes/ } \\
\text { shoot }\end{array}$ & $\begin{array}{l}\text { Callus- } \\
\text { ing }\end{array}$ \\
\hline \multicolumn{7}{|l|}{ BAP } \\
\hline 0.0 & & 49 & $1.0^{\mathrm{i}}$ & $2.2^{\mathrm{e}}$ & $2.39^{\mathrm{d}}$ & - \\
\hline 0.1 & & 55 & $1.1^{\mathrm{i}}$ & $2.17^{\mathrm{e}}$ & $3.1^{\mathrm{b}}$ & - \\
\hline 0.5 & & 70 & $1.86^{\mathrm{g}}$ & $2.34^{\mathrm{d}}$ & $3.1^{\mathrm{b}}$ & - \\
\hline 1.0 & & 80 & $2.4^{\mathrm{d}}$ & $2.4^{\mathrm{d}}$ & $2.9^{\mathrm{b}}$ & - \\
\hline 2.0 & & 79 & $3.6^{\mathrm{b}}$ & $3.57^{\mathrm{b}}$ & $3.6^{\mathrm{a}}$ & + \\
\hline 3.0 & & 69 & $2.5^{\mathrm{c}}$ & $2.4^{\mathrm{d}}$ & $2.43^{\mathrm{cd}}$ & + \\
\hline 4.0 & & 72 & $2.0^{\mathrm{g}}$ & $2.9^{c}$ & $2.44^{\mathrm{d}}$ & ++ \\
\hline 5.0 & & 78 & $1.2^{\mathrm{i}}$ & $2.19^{\mathrm{e}}$ & $2.42^{\mathrm{cd}}$ & ++ \\
\hline \multicolumn{7}{|l|}{$\mathrm{Kn}$} \\
\hline 0.1 & & 66 & $1.1^{\mathrm{i}}$ & $2.38^{\mathrm{d}}$ & $2.98^{\mathrm{b}}$ & - \\
\hline 0.5 & & 69 & $1.2^{\mathrm{i}}$ & $2.4^{\mathrm{d}}$ & $2.76^{\mathrm{c}}$ & - \\
\hline 1.0 & & 78 & $1.2^{\mathrm{i}}$ & $2.74^{\mathrm{b}}$ & $2.74^{\mathrm{c}}$ & - \\
\hline 2.0 & & 71 & $1.2^{\mathrm{i}}$ & $2.38^{\mathrm{d}}$ & $2.76^{\mathrm{c}}$ & - \\
\hline 3.0 & & 70 & $1.1^{\mathrm{i}}$ & $2.4^{\mathrm{d}}$ & $2.44^{\mathrm{cd}}$ & - \\
\hline 4.0 & & 67 & $1.1^{\mathrm{i}}$ & $2.1^{\mathrm{e}}$ & $2.64^{\mathrm{c}}$ & + \\
\hline \multicolumn{2}{|l|}{5.0} & 68 & $1.1^{\mathrm{i}}$ & $2.37^{\mathrm{d}}$ & $2.39^{\mathrm{d}}$ & ++ \\
\hline BAP & IAA & & & & & \\
\hline 1.0 & 0.01 & 51 & $2.3^{\mathrm{e}}$ & $2.66^{\mathrm{b}}$ & $2.9^{\mathrm{b}}$ & - \\
\hline 1.0 & 0.02 & 78 & $5.9^{\mathrm{a}}$ & $3.7^{\mathrm{a}}$ & $3.73^{\mathrm{a}}$ & - \\
\hline 1.0 & 0.05 & 67 & $2.3^{\mathrm{e}}$ & $2.4^{\mathrm{d}}$ & $2.73^{\mathrm{c}}$ & - \\
\hline 1.0 & 0.1 & 65 & $2.2^{\mathrm{f}}$ & $2.3^{\mathrm{d}}$ & $2.2^{\mathrm{e}}$ & + \\
\hline 2.0 & 0.01 & 61 & $2.1^{\mathrm{g}}$ & $2.18^{\mathrm{e}}$ & $2.2^{\mathrm{e}}$ & + \\
\hline 2.0 & 0.02 & 63 & $2.0^{\mathrm{g}}$ & $2.2^{\mathrm{e}}$ & $2.1^{\mathrm{e}}$ & ++ \\
\hline 2.0 & 0.1 & 56 & $1.85^{\mathrm{g}}$ & $1.6^{\mathrm{f}}$ & $2.1^{\mathrm{e}}$ & ++ \\
\hline BAP & NAA & & & & & \\
\hline 1.0 & 0.01 & 65 & $2.0^{\mathrm{g}}$ & $2.42^{\mathrm{d}}$ & $2.5^{\mathrm{cd}}$ & - \\
\hline 1.0 & 0.02 & 61 & $2.3^{\mathrm{e}}$ & $2.39^{\mathrm{d}}$ & $2.45^{\mathrm{cd}}$ & - \\
\hline 1.0 & 0.05 & 63 & $2.1^{\mathrm{g}}$ & $2.2^{\mathrm{e}}$ & $2.44^{\mathrm{d}}$ & + \\
\hline 1.0 & 0.1 & 65 & $2.3^{\mathrm{e}}$ & $2.13^{\mathrm{e}}$ & $2.2^{\mathrm{e}}$ & + \\
\hline 2.0 & 0.01 & 66 & $2.4^{\mathrm{d}}$ & $2.2^{\mathrm{e}}$ & $2.1^{\mathrm{e}}$ & ++ \\
\hline 2.0 & 0.02 & 67 & $2.0^{\mathrm{g}}$ & $2.2^{\mathrm{e}}$ & $2.0^{\mathrm{e}}$ & ++ \\
\hline 2.0 & 0.05 & 68 & $2.0^{\mathrm{g}}$ & $2.4^{\mathrm{d}}$ & $2.1^{\mathrm{e}}$ & ++ \\
\hline 2.0 & 0.1 & 55 & $2.0^{\mathrm{g}}$ & $2.1^{\mathrm{e}}$ & $2.2^{\mathrm{e}}$ & ++ \\
\hline
\end{tabular}

Mean values ( $n=25$ ) within the same column followed by the same subscript(s) are not significantly different $(p \leqslant 0.05)$ according to ANOVA and LSD multiple range test. The + signs indicate intensity of callusing and $\mathrm{a}-$ sign indicates no callusing.

\section{Rooting hardening and establishment}

Roots were not formed during shoot multiplication. When individual shoots of 3-6 cm length were separated and transferred to $\mathrm{SH}$ basal medium containing $3 \%(\mathrm{w} / \mathrm{v})$ sucrose, an initial swelling of the cut ends occurred but no roots were formed. Exogenous supply of auxins was essential for rhizogenesis. Among the three auxins (IAA, IBA, and NAA) tested $1.0 \mathrm{mg} / \mathrm{l}$ IBA (Fig. 1f) induced the formation of up to 4.24 roots
Table 3 Shoot initiation in shoot tip and nodes of different positions of growing shoots of Mahonia leschenaultii cultured in SH agar medium supplemented with $1.0 \mathrm{mg} / \mathrm{l} \mathrm{BAP.}$ Observations were made after 6 weeks.

\begin{tabular}{lcccc}
\hline Explant & $\begin{array}{c}\text { Response } \\
(\%)\end{array}$ & $\begin{array}{c}\text { Mean no. } \\
\text { of shoots }\end{array}$ & $\begin{array}{c}\text { Mean shoot } \\
\text { length }(\mathrm{cm})\end{array}$ & $\begin{array}{c}\text { Mean no. of } \\
\text { nodes/shoot }\end{array}$ \\
\hline Shoot tip & 75 & 1.36 & 2.96 & 2.7 \\
1st node & 67 & 2.6 & 3.16 & 3.1 \\
2nd node & 64 & 2.7 & 4.2 & 3.3 \\
3rd node & 70 & 3.0 & 4.24 & 4.5 \\
4th node & 70 & 3.0 & 4.20 & 5.0 \\
5th node & 79 & 3.8 & 3.8 & 3.2 \\
\hline
\end{tabular}

Mean values $(n=25)$.

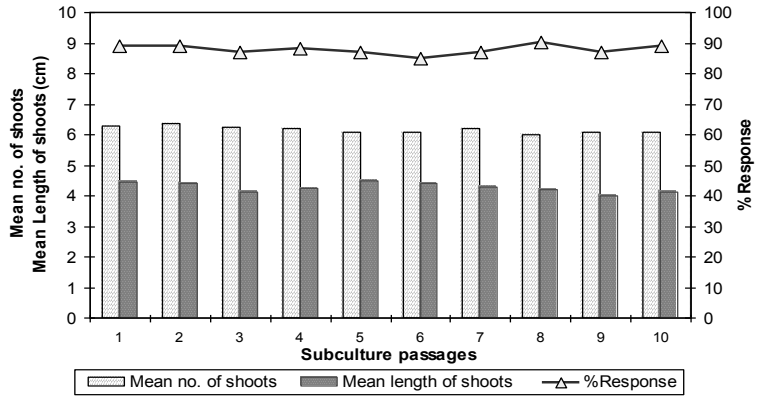

Fig. 2 Multiplication of shoots through successive subculturing of nodal segments from $M$. leschenaultii shoot cultures. SH agar medium containing $0.05 \mathrm{mg} / \mathrm{l}$ and $0.01 \mathrm{mg} / \mathrm{l}$ IAA was used. Observations were made after 6 weeks of each subculture passage.

of $2.43 \mathrm{~cm}$ length in $78 \%$ of the explants in 6 weeks (Table 5). There was no significant difference and number of roots formed between the auxin types. Callusing was conspicuously absent even at the highest concentration of the auxin types tested. The highest percentage establishment in IBA (78\%) was followed by IAA $(67 \%)$ and NAA $(65 \%)$. Hardening of the rooted plants in the mist chamber for at least 3 weeks was essential; otherwise survival rate was reduced to $18-30 \%$. During December-January, $80-82 \%$ of the plants hardened for 4 weeks in the mist chamber were established successfully. However, the shoot cuttings responded favourably to ex vitro rooting as well with high percentage (72-80) root development during hardening in a mixture of river sand and top soil. They produced 4-6 roots within 6 weeks and the rooted plants continued to grow after transfer and subsequently grown for at least 5 weeks in the nursery were transferred to the natural forest segments within the Institute campus to the nursery. The in vitro rooted plants reared for 4-8 weeks in the nursery produced 1-2 new leaves before transfer to the natural forest segments. 
Table 4 Influence of different concentrations of BAP and combinations of BAP and IAA on shoot multiplication during subculture of shoot culture derived node and shoot tip explants of Mahonia leschenaultii cultured in SH agar medium. Data were recorded after 5 weeks of culture.

\begin{tabular}{|c|c|c|c|c|c|c|c|c|c|c|c|}
\hline \multirow{2}{*}{\multicolumn{2}{|c|}{$\begin{array}{c}\text { PGR(s) } \\
(\mathrm{mg} / \mathrm{l})\end{array}$}} & \multicolumn{5}{|c|}{ Node } & \multicolumn{5}{|c|}{ Shoot tip } \\
\hline & & \multirow{2}{*}{$\begin{array}{l}\text { Response } \\
(\%)\end{array}$} & \multirow{2}{*}{$\begin{array}{l}\text { Mean } \\
\text { no. of } \\
\text { shoots }\end{array}$} & \multirow{2}{*}{$\begin{array}{c}\text { Mean } \\
\text { shoot } \\
\text { length } \\
(\mathrm{cm})\end{array}$} & \multirow{2}{*}{$\begin{array}{l}\text { Mean } \\
\text { no. of } \\
\text { nodes/ } \\
\text { shoot }\end{array}$} & \multirow[t]{2}{*}{ Callusing } & \multirow{2}{*}{$\begin{array}{c}\text { Response } \\
(\%)\end{array}$} & \multirow{2}{*}{$\begin{array}{l}\text { Mean } \\
\text { no. of } \\
\text { shoots }\end{array}$} & \multirow{2}{*}{$\begin{array}{c}\text { Mean } \\
\text { shoot } \\
\text { length } \\
(\mathrm{cm})\end{array}$} & \multirow{2}{*}{$\begin{array}{l}\text { Mean } \\
\text { no. of } \\
\text { nodes/ } \\
\text { shoot }\end{array}$} & \multirow[t]{2}{*}{ Callusing } \\
\hline \multicolumn{2}{|l|}{ BAP } & & & & & & & & & & \\
\hline 0.0 & & 90 & $3.4^{\mathrm{e}}$ & $4.10^{\mathrm{b}}$ & $3.0^{\mathrm{c}}$ & - & 63 & $2.0^{\mathrm{b}}$ & $2.27^{\mathrm{a}}$ & $2.3^{\mathrm{b}}$ & - \\
\hline 0.5 & & 89 & $5.5^{\mathrm{b}}$ & $4.42^{\mathrm{a}}$ & $3.9^{\mathrm{b}}$ & - & 77 & $2.28^{\mathrm{a}}$ & $2.13^{\mathrm{b}}$ & $3.2^{\mathrm{a}}$ & - \\
\hline 1.0 & & 92 & $4.6^{c}$ & $4.36^{\mathrm{a}}$ & $3.5^{\mathrm{b}}$ & - & 63 & $2.21^{\mathrm{a}}$ & $2.31^{\mathrm{a}}$ & $2.2^{\mathrm{b}}$ & - \\
\hline 2.0 & & 93 & $4.2^{\mathrm{d}}$ & $3.58^{\mathrm{c}}$ & $3.3^{c}$ & - & 61 & $2.0^{\mathrm{b}}$ & $2.2^{\mathrm{b}}$ & $2.01^{\mathrm{b}}$ & - \\
\hline 3.0 & & 80 & $4.1^{\mathrm{d}}$ & $3.47^{\mathrm{c}}$ & $3.1^{\mathrm{c}}$ & + & 87 & $1.9^{\mathrm{b}}$ & $2.01^{\mathrm{c}}$ & $1.8^{\mathrm{c}}$ & + \\
\hline 4.0 & & 83 & $3.9^{\mathrm{d}}$ & $3.41^{\mathrm{c}}$ & $3.1^{\mathrm{c}}$ & ++ & 76 & $1.9^{\mathrm{b}}$ & $1.91^{\mathrm{c}}$ & $1.5^{\mathrm{d}}$ & ++ \\
\hline 5.0 & & 78 & $3.5^{\mathrm{e}}$ & $3.37^{\mathrm{cd}}$ & $2.9^{\mathrm{cd}}$ & ++ & 66 & $1.5^{\mathrm{c}}$ & $1.2^{\mathrm{d}}$ & $1.6^{\mathrm{c}}$ & ++ \\
\hline BAP & IAA & & & & & & & & & & \\
\hline 0.5 & 0.01 & 92 & $6.2^{\mathrm{a}}$ & $4.41^{\mathrm{a}}$ & $4.3^{\mathrm{a}}$ & - & 78 & $1.64^{\mathrm{c}}$ & $2.13^{b}$ & $1.8^{\mathrm{c}}$ & + \\
\hline 0.5 & 0.05 & 92 & $5.0^{c}$ & $4.00^{\mathrm{b}}$ & $3.2^{\mathrm{c}}$ & - & 71 & $1.34^{\mathrm{d}}$ & $2.10^{\mathrm{b}}$ & $1.4^{\mathrm{d}}$ & + \\
\hline 0.5 & 0.1 & 86 & $2.3^{\mathrm{e}}$ & $3.30^{\mathrm{cd}}$ & 2.9 & + & 68 & $1.52^{\mathrm{c}}$ & $1.3^{\mathrm{d}}$ & $1.3^{\mathrm{d}}$ & ++ \\
\hline 1.0 & 0.01 & 97 & $2.1^{\mathrm{f}}$ & $3.20^{\mathrm{cd}}$ & $2.8^{\mathrm{cd}}$ & - & - & & & & \\
\hline 1.0 & 0.05 & 94 & $2.0^{\mathrm{f}}$ & $2.80^{\mathrm{d}}$ & $2.7^{\mathrm{d}}$ & + & - & & & & \\
\hline 1.0 & 0.1 & 89 & $2.0^{\mathrm{f}}$ & $2.30^{\mathrm{d}}$ & $2.7^{\mathrm{d}}$ & ++ & - & & & & \\
\hline
\end{tabular}

Mean values ( $n=25$ ) within the same column followed by the same subscript(s) are not significantly different $(p \leqslant 05)$ according to ANOVA and LSD multiple range test. The + signs indicate intensity of callusing and a - sign indicates no callusing.

\section{Restoration to natural forest habitat}

The micropropagated plants of $M$. leschenaultii planted into the field gene bank of Institute campus showed $80 \%$ establishment rate after 18 months and those reintroduced into Vattakanal shola forests at Palani hills got established at the highest rate of $90.6 \%$ (Table 6). While the plants transferred to Palani hills grew very fast and attained a length of $1 \mathrm{~m}$ with 5-7 new leaves within 6 months, those introduced into the forest segments of the Institute showed poor growth. There was no loss of plants in both the locations after 18 months. Plants established each location exhibited similar morphological and growth characteristics (Fig. 1g and 1h) free of abnormalities.

\section{GENETIC UNIFORMITY}

\section{Random amplified polymorphic DNA analysis}

PCR amplification products obtained for 15 primers from the conventionally propagated plants and micropropagated plants resolved on $1.3 \%$ agarose gel showed 98\% similarity and fidelity. Polymorphic banding profile of amplified product from representative samples produced by the oligo primer is presented in Fig. 3.

\section{DISCUSSION}

A major objective of the present investigation was to develop a micropropagation system that could be used as a crisis management tool for the conservation of M. leschenaultii, a species otherwise sparsely distributed and fast declining in its native habitats on the hill tops of the Western Ghats in southern India. At present, this species is lesser known as a source of berberine and is often riddled with such biotic bottlenecks as seed sterility, seed recalcitrance and absence of vegetative propagules and subjected to all sorts of hazards including outright clearing of the natural stands due to increased human inhabitation and conversion of vast stretches of forest lands for hill crop cultivation. The ready availability of micropropagated systems may spur economic cultivation of the species for future industrial raw material supply, if it is developed as an economic crop for the extraction of berberine.

A series of experiments were performed to devise a suitable micropropagation method using the shoot tips, foliar, internodal and nodal segments of actively growing shoots. Culture of the explant types on basal and supplemented nutrient media suggested that 
Table 5 Rhizogenic response of shoots transferred to SH medium containing different concentrations of auxins. Observations were made 6 weeks after transfer.

\begin{tabular}{lcccc}
\hline Auxin & $\begin{array}{c}\text { Rooting } \\
(\%)\end{array}$ & $\begin{array}{c}\text { Mean no. } \\
\text { of roots }\end{array}$ & $\begin{array}{c}\text { Mean root } \\
\text { length }(\mathrm{cm})\end{array}$ & Callusing \\
\hline 0.0 & - & - & - & - \\
IAA & & & & \\
0.05 & 68 & $2.37^{\mathrm{c}}$ & $1.4^{\mathrm{d}}$ & - \\
0.1 & 67 & $2.7^{\mathrm{b}}$ & $1.5^{\mathrm{d}}$ & - \\
0.5 & 66 & $2.67^{\mathrm{b}}$ & $2.1^{\mathrm{c}}$ & - \\
1.0 & 67 & $4.24^{\mathrm{a}}$ & $2.43^{\mathrm{a}}$ & - \\
2.0 & 64 & $2.1^{\mathrm{d}}$ & $2.1^{\mathrm{c}}$ & + \\
IBA & & & & \\
0.05 & 67 & $2.1^{\mathrm{d}}$ & $2.3^{\mathrm{b}}$ & - \\
0.1 & 73 & $2.36^{\mathrm{c}}$ & $2.1^{\mathrm{c}}$ & - \\
0.5 & 74 & $2.4^{\mathrm{c}}$ & $2.3^{\mathrm{b}}$ & - \\
1.0 & 78 & $4.23^{\mathrm{a}}$ & $2.41^{\mathrm{a}}$ & - \\
2.0 & 71 & $2.1^{\mathrm{d}}$ & $2.13^{\mathrm{c}}$ & - \\
NAA & & & & \\
0.05 & 67 & $2.1^{\mathrm{d}}$ & $1.3^{\mathrm{d}}$ & - \\
0.1 & 61 & $2.2^{\mathrm{d}}$ & $2.3^{\mathrm{b}}$ & - \\
0.5 & 62 & $2.2^{\mathrm{d}}$ & $2.3^{\mathrm{b}}$ & - \\
0.1 & 61 & $2.4^{\mathrm{c}}$ & $2.39^{\mathrm{a}}$ & - \\
0.5 & 64 & $2.1^{\mathrm{d}}$ & $2.1^{\mathrm{c}}$ & - \\
1.0 & 65 & $4.21^{\mathrm{a}}$ & $2.1^{\mathrm{c}}$ & - \\
2.0 & 61 & $2.2^{\mathrm{d}}$ & $2.0^{\mathrm{c}}$ & + \\
\hline
\end{tabular}

Mean values ( $n=25)$ within the same column followed by the same subscript(s) are not significantly different $(p \leqslant 0.05)$ according to ANOVA and LSD multiple range test. The + signs indicate intensity of callusing and $\mathrm{a}-$ sign indicates no callusing.

Table 6 Establishment of micropropagated plants of M. leschenaultii reintroduced into various forest segments.

\begin{tabular}{lcccc}
\hline Location & No. of plants & \multicolumn{3}{c}{ Establishment (\%) } \\
\cline { 3 - 5 } & reintroduced & 4 months & 8 months & 10 months \\
\hline Palode & 200 & $152(76)$ & $149(74.5)$ & $149(74.5)$ \\
Palani hills & 200 & $186(93)$ & $183(91.5)$ & $180(90.0)$ \\
\hline
\end{tabular}

only explants having resident meristems responded favourably with bud break and growth of the bud into $1-2 \mathrm{~cm}$ shoot in $1-2$ weeks. Bud initiation in meristematic explant desirable to produce uniform plants free of abnormalities ${ }^{13}$. Caulogenic response was induced by SH more than WP, MS and B5 basal nutrient media. Perusal of the literature reveals that MS is the medium of choice for a number of species including the woody ones. However, this preference is not universal as tissue culture of such woody species as Prunus ${ }^{14}$, Camptotheca accuminata ${ }^{15}$, Adhatoda beddomei ${ }^{16}$, and Woodfordia fruticosa ${ }^{17}$ has been

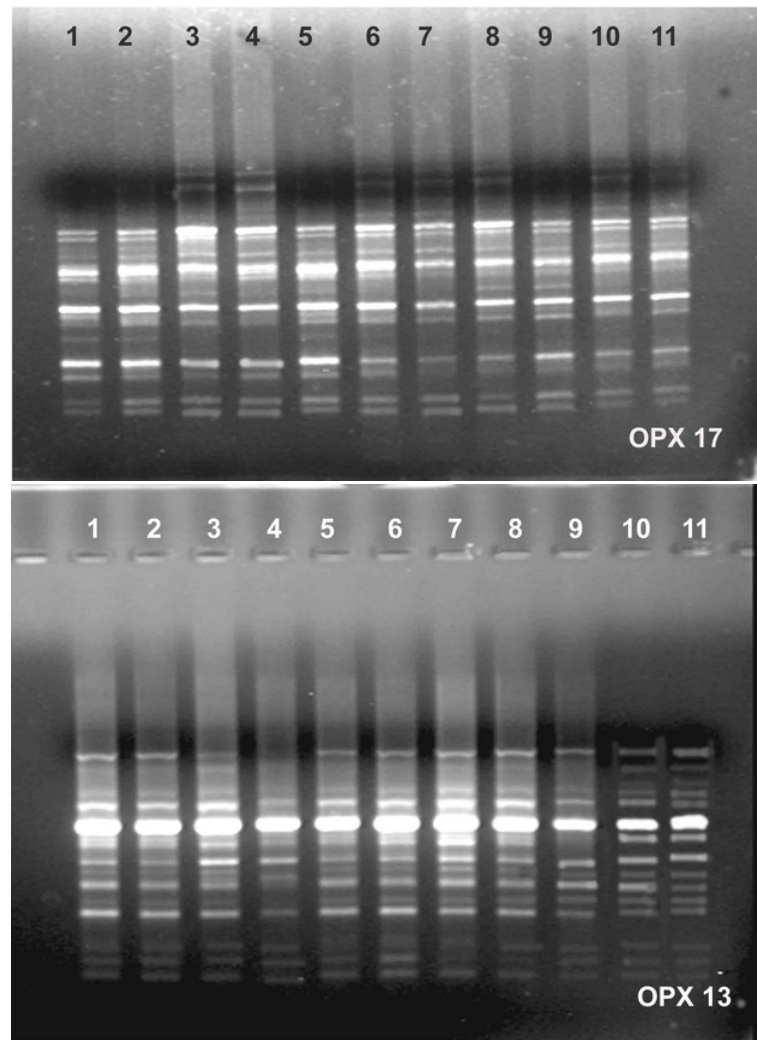

Fig. 3 RAPD profiles of conventionally propagated plants (lane 1) and micropropagated plants (lane 2-10) - polymorphic banding profile produced by the oligo primer OPX 17 or OPX 13.

successfully accomplished in other nutrient formulations. In general, because of its toxicity, many workers have preferred to use low concentrations of $\mathrm{NH}_{4}^{+}$ ions and high concentrations of ammonium nitrate in the medium is known to cause hyperhydricity of the cultured plants ${ }^{18}$. Comparison of the mineral composition of the media indicates that SH like the B5 medium has substantially reduced ammonium and calcium ion concentrations but more than double the concentrations of phosphorus ions over all the other media tested. The enhanced percentage of bud break in SH medium might therefore be attributed more to high concentration of phosphorus ions than to reduced levels of $\mathrm{NH}_{4}^{+}$. This in vitro response may be a reflection of the adaptations of this species to forest soils of the Western Ghats that are otherwise rich in phosphorus ${ }^{19}$. It was evident from the results presented in Tables 1 and 2 that the nodal explants are a better source of shoot formation than the shoot tips, despite the presence of both the apical and axillary meristems in the latter. Solitary shoot 
formation observed in most of the shoot tips and only an additional shoot in the rest, is presumably due to increased apical dominance, which is not uncommon in woody species ${ }^{20}$. The shoots initially regenerated from an explant may also suppress further development of shoot ${ }^{21}$. However, how the assured apical buds released for proliferation were under the influence of high concentrations of exogenously added cytokinin (BA) remains to be explained. Given the situation where the auxin synthesized in the apical meristem moves basipetally along the length of the growing shoot, the axillary meristems located at varying distances from the tip would be naturally subjected to differential influences of the apical dominance. Therefore, the nodal meristems present in the first visible node subtending the shoot tip and under greater influence of the apical dominance activity of the shoot tip to form a fewer (2.6) shoots than the distal fifth node (3.8) is not surprising. It is a different matter that for maximum caulogenic response the explants have to be isolated during the growing season (MayJuly) when under the influence of pre-monsoon and monsoon rains, most of the buds are relieved of natural dormancy. Besides, unlike the inhibitory influence of the exudates observed in tissue cultures of the related Berberis thunbergii ${ }^{7}$, yellowish exudate from the cut ends of all the explant types presumably rich in berberine were not at all inhibitory to shoot initiation. A striking similarity could be found in Nandina, where neutral effect of phenolic exudate released from the wounded sites was reported ${ }^{22}$. In Betula pendula, buds in culture released greatest amount of phenolic substances into the medium and exhibited significant growth and development in vitro ${ }^{23}$. Supplementation of SH medium with cytokinin was essential to obtain multiple shoot formation in both shoot tip and nodal cultures. The observation that BA induced more shoots than $\mathrm{Kn}$ in both the explants types indicated the stronger cytokine activity and accordingly the desirability of using the former for shoot initiation and multiplication. The relative merit of using BA compared to other cytokines for shoot initiation in tissue culture of a number of species including the arborescent ones has been well documented ${ }^{24}$. The relatively low concentration of $(<1.0 \mathrm{mg} / \mathrm{l}) \mathrm{BA}$ required to induce multiple bud formation in shoot tips compared to the nodes $(2.0 \mathrm{mg} / \mathrm{l})$ could be ascribed to the functional status of the meristems per se. The meristems, which are already active, in a growing shoot, required lower concentration of the cytokinin than its relative clonal axillary buds.

The maximum number of shoot formation, as observed in the nodal explant cultures, however, required a synergistic combination of cytokinin BAP $(1.0 \mathrm{mg} / \mathrm{l})$ and auxin IAA $(0.02 \mathrm{mg} / \mathrm{l})$ that is in consonance with the published papers on such other woody species as Aegle marmelos ${ }^{25}$ and Adhatoda beddomei ${ }^{16}$. The increase in shoot number from 3.6-5.9 occurred in this specific combination despite the fact that the optimal individual concentration of BAP $(2.0 \mathrm{mg} / \mathrm{l})$ worked out earlier was reduced to half. Besides the significant increase in the number of shoots did not affect the growth of the shoots as evidenced from the measured length of the shoots and number of nodes per shoot (Table 5). It was also of interest to note that even at the optimal concentrations and combinations of growth regulators tested, multiple shoot formation occurred in two stages; initially the resident meristem developed into a single shoot of 1.0-1.8 cm length in 1-2 weeks and then additional shoots differentiated from its base. The observation that further growth of the resident meristem-derived shoot got arrested after the differentiation of these buds probably indicates that the additional buds were actually formed from the basal node of the first formed shoot and not from the adventive meristems. Since the nutrients and growth factors are now mobilized and directed to flow towards the newly developed active sites of caulogenesis, their availability for the continued growth of the first formed shoot may be reduced with the consequent decline of its growth. Somewhat similar results were reported in single node culture of Vanda spathulata where the early formed growth of the single axillary shoot slowed down with the sprouting of additional buds sprouted from its base ${ }^{26}$. The rapid growth of the additional shoots could eventually catch up with the first formed shoot so that all the shoots differentiated upon the nodes were more or less of the same length after 6 weeks of culture.

The morphogenetic responses of the subcultured shoot apices and nodes derived from shoots raised in vitro closely mirrored those of the primary explants used for culture initiation, though the concentrations of the growth regulators were suitably reduced and both the frequency and number of shoots formed were of higher order. A reduction in the concentration of the growth regulators during subculture is usually followed in tissue culture of many plants consequent to the acclimatization of the primary cultures to the chemical nutrient milieu or the continued use of high concentration of BA posed problem of nitrification and development of inseparable clusters of shoots 27 . However, for optimal shoot production during subculture as well, the ratio of BA/IAA needs to be maintained in the synergistic combination. That shoot production continued through 10 subculture passages 
without decline, morphological and growth abnormalities indicated the desirability of reducing the concentration of the growth regulators and the balance between BA and IAA for subcultures. The shoots so obtained through successive subculture were also easily rooted at $78 \%$ rate in the presence of IBA/IAA. The literature available on woody plant tissue culture shows that with few exceptions, rooting is either difficult or only partially achieved and usually the shoots are transferred to media drained of nutrients ${ }^{25,28}$ to induce rooting.

Our observations of the micropropagated plants at the post transplantation stage suggest that rearing of the hardened plants in the nursery exposed to semiambient conditions at least for a 5-8 week period is essential to make them attain certain level of acclimatization, hardening and growth before they are transferred to the field. Amplification products were uniformly monomorphic and no change in RAPD profile was detected between the conventionally propagated plant and the ten randomly selected clonal plants. Similar observations were reported in Valeriana wallichii ${ }^{29}$. Both isozyme and RAPD assays have offered reasonable means to assess the genetic fidelity of micropropagated plants in other species ${ }^{30}$. It is not surprising that the in vitro cultured plants reintroduced into Vattakanal forests habitats in Palani hills with favourable microclimatic conditions performed better with high percentage establishment and profuse growth as evidenced from formation in quick succession of new leaves in relation to that of the plants in the Institute campus. However, considering the phenomenal differences in altitude and climatic conditions affecting the growth of the plants recorded in both the locations, significant percentage $(80 \%)$ establishment of the plants in the tropical humid forests of Palode, however minimal the growth may be, is interesting. It is possible that $M$. leschenaultii is a neutral species with flexible adaptation and the established micropropagated plants at low altitudes showed normal growth characteristics. The successful naturalisation of the micropropagated plants and recovery of $M$. leschenaultii certainly lead to the view that process of micropropagation and ecorestoration is an efficient tool to supplement the conservation efforts ${ }^{31}$. Overall, this study comprising the development of an in vitro propagation protocol, assessment of the micropropagated plants for quality assurance and recovery of the plants through reintroduction into native and alien habitats together provide a comprehensive package for the conservation and sustainable use of target species.

\section{REFERENCES}

1. Wochok ZS (1992) The commercial pathway for agricultural biotechnology. In: Gresshoff PM (ed) Plant Biotechnology and Development. Boca Raton: CRC Press pp 147-54.

2. Ahmedhullah M, Nayar MP (1986) Endemic Plants of the Indian Region. Botanical Survey of India.

3. Čerňáková M, Košt'álová D, Kettmann V, Plodová M, Tóth J, Dřímal J (2002) Potential antimutagenic activity of berberine, a consistent of Mahonia aquifolium. BMC Compl Alternat Med 2, 2.

4. Council of Scientific Industrial Research (1959) The Wealth of India: Raw Materials vol. V. New Delhi. p 111.

5. Rajan S, Sethuraman M (1992) Mahonia leschenaultii - a Toda plant. Ancient Sci Life 12, 242-4.

6. Li XK, Motwani M, Tong W, Bornmann W, Schwartz GK (2000) Huanglian, a Chinese herbal extract, inhibits cell growth by suppressing the expression of cyclin B1 and inhibiting CDC2 kinase activity in human cancer cells. Mol Pharmacol 58, 1287-93.

7. Karhu ST, Hakala K-L (1991) Micropropagation of Berberis thunbergii. Acta Hort 289, 119-20.

8. Sato F, Yamada Y (1984) High berberine producing cultures of Coptis japonica cells. Phytochemistry 23, 281-5.

9. Ikuta A, Itokawa H (1982) Berberine and other proto berberine alkaloids in callus tissue of Thalictrum minus. Phytochemistry 21, 1419-21.

10. Jayakumaran Nair A, Sudhakaran PR, Rao M, Ramakrishna SV (1992) Berberine synthesis by callus and cell suspension cultures of Coscinium fenestratum. Plant Cell Tissue Organ Cult 29, 7-10.

11. Schenk RU, Hilderbraandt AC (1972) Medium and techniques and growth of monocotyledonous and dicotyledonous plant cell cultures. Can J Bot 50, 199-204.

12. Muray MG, Thomson WF (1980) Rapid isolation of high molecular weight DNA. Nucleic Acids Res 8, 4321-5.

13. Bajaj YPS, Furmanowa M, Olszowskao O (1988) Biotechnology of the micropropagation of medicinal and aromatic plants. In: Bajaj YPS, ed. Biotechnology in Agriculture and Forestry. Vol 4 New York: SpringerVerlag, pp 60-103.

14. Harada H, Murai Y (1996) Micropropagation of Prunus mume. Plant Cell Tissue Organ Cult 46, 265-7.

15. Jain AK, Nesseler CL (1998) Clonal propagation of Camtotheca through shoot bud culture. Plant Cell Tissue Organ Cult 44, 229-33.

16. Sudha CG, Seeni S (1994) In vitro multiplication and field establishment of Adhatoda beddomei C.B. Clarke, a rare medicinal plant. Plant Cell Rep 13, 203-7.

17. Krishnan PN, Seeni S (1994) Rapid micropropagation of Woodfordia fruticosa (L.) Kurz (Lythracea), a rare medicinal plant. Plant Cell Rep 14, 55-8. 
18. Brand MH (1993) Agar and ammonium nitrate influence hyperhydricity, tissue nitrate and total nitrogen content of serviceberry (Amelanchier arborea) shoots in vitro. Plant Cell Tissue Organ Cult 35, 203-9.

19. Chandrasekhara UM, Ramakrishna PS (1994) Sucessional patterns and gap phase dynamics of humid tropical forest of the Western Ghats of Kerala, India. Ground vegetation, biomass, productivity and nutrient cycling. Forest Ecol Manag 70, 23-40.

20. Hu CY, Wang PJ (1983) Meristem, shoot tip and bud culture. In: Evans DA, Sharp WR, Ammirato PV, Yamada Y (eds) Handbook of Plant Cell Culture. 1 Macmillan Publishing Co., New York. pp 177-227.

21. Douglas GC, Retledge CB, Casey AD (1989) Micropropagation of Floribunda, gound cover and miniature roses. Plant Cell Tissue Organ Cult 19, 55-64.

22. Gould JB, Murashige T (1995) Morphogenic substances released by plant tissue cultures. Plant Cell Tissue Organ Cult 4, 29-42.

23. Welander M (1998) Biochemical and anatomical studies of birch (Betula pendula Roth.) buds exposed to different climatic conditions in relation to growth in vitro. In: Hanover JW, Keathley DE (eds) Genetic Manipulation of Woody Plants. Plenum, New York, pp 79-99.

24. Baruach A, Nagarajan V, Parthasarathy VA (1996) Micropropagation of three endangered citrus species. Ann Plant Physiol 10, 124-5.

25. Ajithkumar D, Seeni S (1998) Rapid clonal multiplication through in vitro axillary shoot proliferation of Aegle marmelos (L.) corr., a medicinal tree. Plant Cell Rep 17, 422-6.

26. Decruse SW, Seeni S, Gangaprasad A, Sarojini Menon V (2003) Micropropagation and ecorestoration of Vanda spathulata, an exquisite orchid. Plant Cell Tissue Organ Cult 72, 199-202.

27. Gangopadhyay T, Gangopadhyay G, Poddar Rand Mukherjee KK (2004) Trichomes: their diversity in acclimatization of Tectona grandis L. Plant Cell Tissue Organ Cult 78, 113-21.

28. Sudha CG, Seeni S (1996) In vitro propagation of Rauvolfia micrantha, a rare medicnal plant. Plant Cell Tissue Organ Cult 44, 243-81.

29. Verma P, Srivastava P, Singh S, Mathur A (2010) Genetic fidelity of long-term micropropagated plantlets of Valeriana wallichii-an endangered medicinal plant. Curr Sci 99, 436-8.

30. Goto S,Thakur RC, Ishii K (1998) Determination of genetic stability in long term micropropogated shoots of Pinus thumbergii Part, using RAPD markers. Plant Cell Rep 18, 193-7.

31. Fay MF (1994) In what situation is in vitro cultures appropriate to plant conservation? Biodiversity Conserv 3, 176-83. 